\title{
Xenotransplantation: A potential solution to the critical organ donor shortage
}

\author{
K Howe Sim MD FRCPC, Anton Marinov, Gary A Levy MD FRCPC
}

\begin{abstract}
KH Sim, A Marinov, GA Levy. Xenotransplantation: A potential solution to the critical organ donor shortage. Can J Gastroenterol 1999;13(4):311-318. The success of allotransplantation as a treatment for end-stage organ failure has resulted in the need for an increasing number of organ donors. Attempts to meet this need include the use of organs from living related and unrelated donors, financial or other incentives for the donor family, and even the reuse of transplanted organs. Despite these initiatives, the supply of organs for transplantation still falls far short of the demand, as evidenced by longer waiting times for transplantation and decreasing transplantation rates. Even if Canada were able to increase its organ donor rate to that of Spain (40 to 50/million), where organ donation is governed by 'presumed consent' legislation, this would not alleviate the problem of donor shortage. Interest in xenotransplantation stems from the need to overcome this increasingly severe shortage of human organs. Indeed, some argue that xenotransplantation is the only potential way of addressing this shortage. As immunological barriers to xenotransplantation are better understood, those hurdles are being addressed through genetic engineering of donor animals and the development of new drug therapies. However, before xenotransplantation can be fully implemented, both the scientific/medical communities and the general public must seriously consider and attempt to resolve the many complex ethical, social and economic issues that it presents.
\end{abstract}

Key Words: Liver disease; Organ donation; Thrombosis; Xenotransplantation; Zoonosis

\section{Xénotransplantation : solution potentielle à la} pénurie critique de donneurs d'organes

RÉSUMÉ : La réussite de l'allotransplantation, en traitement de l'insuffisance organique terminale, a mis au jour le besoin de trouver plus de donneurs d'organes. Pour tenter de résoudre le problème, on a, par exemple, recours aux organes de donneurs vivants apparentés ou non au receveur. On a mis de l'avant des incitatifs d'ordre économique ou autre à l'intention des familles des donneurs et on a même tenté de réutiliser des organes transplantés. Malgré ces initiatives, l'approvisionnement en organes transplantables ne répond pas à la demande comme en fait foi le temps d'attente toujours plus long pour les transplantations et la baisse des taux de transplantations. Même si le Canada arrivait à augmenter le nombre de donneurs d'organes pour atteindre celui de l'Espagne ( 40 à $50 /$ million) où le don d'organes est régi par une loi de "consentement présumé ", cela ne règlerait pas le problème de pénurie de donneurs. L'intérêt à l'endroit de la xénotransplantation découle de la nécessité de surmonter ce problème toujours plus grand de pénurie d'organes humains. En effet, selon certains, la xénotransplantation est la seule façon potentielle de répondre à la carence. À mesure que les barrières immunologiques à la xénotransplantation seront mieux comprises, elles seront sur la voie d'être abolies, grâce au génie génétique appliqué à des animaux donneurs et grâce au développement de nouvelles pharmacothérapeutiques. Par contre, avant que le recours à la xénotransplantation ne se répande, les communautés scientifiques et médicales et le grand public devront se pencher sur les nombreux problèmes déontologiques, sociaux et économiques complexes associés à cette solution.

Dr K Howe Sim is the recipient of a Research Fellowship from the Canadian Association for the Study of the Liver and Glaxo Wellcome Canada

Multiorgan Transplant Research Unit, The Toronto Hospital, University of Toronto, Toronto, Ontario

Correspondence and reprints: Dr Gary A Levy, The Toronto Hospital, NU-10-151, 621 University Avenue, Toronto, Ontario M5G 2C4. Telephone 416-340-5166, fax 416-340-3378, email fgl2@msn.com 
$\mathrm{O}$ rthotopic liver transplantation is the treatment of choice for many patients with end-stage liver disease. Advances in immunosuppression and perioperative care have resulted in a dramatic improvement in survival of patients undergoing liver transplantation (1). However, the need for donor organs far outweighs the available supply (Table 1) (2-5). This need has prompted the search for alternatives to conventional allotransplantation $(6,7)$. Xenotransplantation, the transplantation of cells, tissues or organs between members of different species, has emerged as a potential solution to the shortage of human organs. The concept of transplanting animal organs into humans is not new. The first such attempt was made by a Russian physician in 1682, who reportedly repaired the skull of a wounded nobleman by using a bone from a dog (8). In 1964, kidneys from chimpanzees were transplanted into 13 patients (9). Most died within days, although one survived for nine months on an immunosuppressive regimen of azathioprine, actinomycin $\mathrm{C}$ and steroids. More recently, two patients received liver transplants from baboons. One patient survived for more than two months, but ultimately both patients died due to infection (10).

The preferred source of the xenograft is a concordant species that is closely related to the recipient (eg, nonhuman primate to human). Discordant xenotransplantation (eg, pig to human) involves widely divergent species. While it is much easier to achieve xenograft acceptance across concordant combinations, the widespread use of primates as donors (such as baboons and chimpanzees) poses a number of problems. These problems include ethical issues (eg, 'humanization of primates'), limited availability, small size and risk of transmitting infectious agents (11). For these reasons, it is likely that a species discordant with humans will offer a source of organs for xenotransplantation. The use of pigs as a source of donor organs is attractive for reasons including their similar size and physiology, their availability in sufficient quantities and the fact that they can be bred under controlled conditions where their make-up can be genetically modified.

In addition to overcoming the immunological barriers raised by cross-species transplantation, a number of complex ethical, social, legal and economic principles must be addressed. A thorough evaluation and understanding of the safety, efficacy and risks of xenotransplantation are necessary prerequisites to the widespread clinical application of this potential future therapy.

\section{HYPERACUTE REJECTION}

The first immunological barrier to xenotransplantation is hyperacute rejection (HAR), characterized by complement activation leading to widespread thrombosis and interstitial hemorrhage of the donor organ (12). This phenomenon is initiated by the binding of antibodies of the recipient to the vascular endothelium of the donor organ (13). These naturally occurring 'xenoreactive' antibodies (XRAs) recognize cells from discordant species, and are present in humans and other Old World primates (14).
TABLE 1

The need for solid organ transplantation in Canada

\begin{tabular}{lrcrr}
\hline & \multicolumn{4}{c}{ Number of organs required/year } \\
& Liver & Kidney & Lung & Heart \\
\hline Transplants needed & 3600 & 5900 & 6100 & 6600 \\
Transplants performed & 318 & 940 & 80 & 180 \\
\hline
\end{tabular}

Data from reference 77

XRAs react predominantly to the carbohydrate epitope Gal-alpha-1,3-Gal, which is expressed as a terminal modification on glycoproteins and glycolipids of New World monkeys and all lower mammals (15). Synthesis of Galalpha-1,3-Gal is catalyzed by alpha-1,3galactosyltransferase, an enzyme that is absent in humans, apes and baboons (16). Evidence that Gal-alpha- 1,3-Gal is a critical target in HAR of pig to primate xenografts came from the demonstration by Collins et al (17) that transplantation of a New World monkey heart into a baboon results in HAR, and that virtually all the antibodies that bind to the rejected heart are specific for Galalpha-1,3-Gal. Sachs and Sablinski (18) subsequently demonstrated that specific depletion of anti-Galalpha-1,3-Gal antibodies from primates prevents HAR of porcine xenografts.

Activation of complement is a crucial step in the development of HAR. Administration of complement inhibitors such as cobra venom factor $(19,20)$, soluble complement receptor type 1 (21) or gamma globulin (22) markedly prolongs the survival of a discordant xenograft. HAR does not occur in recipients with inherited deficiencies of complement (23). In porcine to primate xenografts, complement activation appears to occur predominantly via the classical pathway (24). Because complement activation plays a pivotal role in the pathogenesis of HAR, the ability to regulate human complement may help overcome a major hurdle in the clinical application of xenotransplantation. One way to regulate complement activation may be through membrane-bound regulators of complement activity that inhibit the complement cascade at various critical steps (25). Examples of such regulators are decay accelerating factor (DAF [CD55]) (26), which promotes dissociation of convertase complexes; membrane cofactor protein (MCP [CD46]), which inhibits complement activation at the $\mathrm{C} 3$ convertase step; and membrane inhibitor of reactive lysis (CD59), which prevents assembly of lytic membrane attack complexes (27). These glycoproteins help protect autologous (ie, host) cells against inadvertent complement-mediated injury targeted against xenogeneic cells. Complement regulatory proteins appear to function poorly against heterologous complement and thus may make xenografts particularly susceptible to complementmediated injury (28). For example, human DAF inhibits human $\mathrm{C} 3$ convertases effectively but rabbit $\mathrm{C} 3$ convertases poorly (29). The importance of complement regulation is suggested by the observation by McCurry et al (30) that organs from transgenic pigs expressing human CD55 and 
CD59 generally resist HAR after transplantation into baboons.

The precise mechanism by which complement activation leads to destruction of the donor organ is not well understood but appears to involve loss of function of endothelial cells. Complement-mediated lysis of endothelial cells alone is not the sole mechanism because lysis is not a major finding early in the course of HAR (12). One noncytotoxic change in the endothelium that may lead to loss of endothelial barrier function is the formation of intercellular 'gaps' induced by C5b67 complexes - gaps that may allow platelet adhesion and activation (31). This change may also lead to loss from endothelium of heparan sulphate, a protein polysaccharide conjugate that contributes to the endothelial barrier to blood cells and proteins, anticoagulation, and protection against complement and oxidants $(32,33)$. Other complement-mediated changes that may contribute to the manifestations of HAR are the secretion of von Willebrand factor (34), which may trigger platelet aggregation, and the expression of P-selectin (35), which can serve as a ligand for neutrophils and platelets.

Therefore, efforts to prevent HAR can focus on modifying the immune system of the host (either targeting natural antibody reactivity or inhibiting complement activation) or modifying the donor organ to diminish their immunogenicity. Depletion of XRA with plasmapheresis, plasma exchange, anti-idiotypic antibody and extracorporeal immunoadsorption in pig to primate xenografting has, at best, prolonged graft survival from several hours to two weeks, making these approaches to block antibodyinduced HAR clinically unattractive (36). Neutralizing anti-Gal-alpha- 1,3-Gal antibody by continuous intravenous infusion of Gal-alpha-1,3-Gal oligosaccharides leaves few antibodies to bind to the xenograft and has met with some success in prolonging graft survival (37). Attention has recently turned towards suppressing the activity of B cells involved in anti-Gal-alpha-1,3-Gal antibody production by administering a Gal-alpha-1,3-Gal oligosaccharide to which a toxin has been attached (38). Decomplementing the xenograft recipient with cobra venom factor or similar agents also only provides several days of graft survival and is, therefore, a less than ideal therapy $(19,20)$.

Another strategy for disrupting antibody-antigen reactions focuses on reducing the expression of antigen in xenograft donors. An alpha-1,3-galactosyltransferase knockout mouse has been developed that does not express Gal-alpha-1,3-Gal, although this process has yet to be carried out in pigs (39). A similar approach is to exploit natural variations in antigen expression by breeding donors with low antigen expression of Gal-alpha-1,3-Gal (40). The alternative approach of competitive glycosylation replaces the alpha-Gal molecule with an oligosaccharide against which humans do not possess antibody (such as the O blood group oligosaccharide alpha-Fuc), and has been used in mice (41) and pigs (42). Finally, much attention has recently focused on the creation of pigs transgenic for one of the human regulators of complement activation. Organs from transgenic pigs expressing low levels of human CD55 and CD59 resisted complement-mediated injury and HAR after transplantation into baboons (30).

\section{DELAYED XENOGRAFT REJECTION}

If HAR is averted, xenografts are still rejected in days instead of minutes or hours by a process referred to as ' $d$ elayed xenograft rejection' (DXR), also termed 'acute vascular xenograft rejection' (19). This process is characterized pathologically by infiltration of leukocytes (particularly monocytes and natural killer [NK] cells), focal ischemia and diffuse microvascular coagulation (43). There is increasing evidence that DXR may be caused by the ongoing interaction of XRA with the graft. Development of DXR coincides with a marked increase in the synthesis of XRA after exposure to xenogeneic cells (44). Furthermore, removal and/or inhibition of XRA from xenograft recipients delays or prevents DXR (45). In contrast to HAR, the role of the complement system in the pathophysiology of DXR is unclear. DXR typically occurs in xenograft recipients depleted of complement (43). Yet the pathologic lesions characteristic of DXR appear to reflect complement-mediated changes in endothelial structure and function. Hancock (46) hypothesized that even the most potent inhibitors of complement, such as cobra venom factor, are incompletely effective. While such treatments may reduce complement to levels that do not result in HAR, there may still be sufficient complement activity in serum to contribute to the development of DXR. Other possible effector mechanisms for DXR include the action of host platelets and leukocytes on the xenograft. Platelets activated by exposure to complement fragments express $\mathrm{P}$-selectin, resulting in the release of potent chemotactic signals, such as RANTES and MCP-1, that attract leukocytes, particularly monocytes (47). The presence of both monocytes and NK cells has been documented in organs with DXR $(19,43)$. Treatment of xenograft recipients with antibodies that inhibit the function of inflammatory cells has been shown to prolong graft survival (48). Some studies suggest that NK cells act by disrupting the integrity of the endothelial monolayer (49) and by activating endothelial cells (50). Endothelial activation in animal models of DXR has been associated with a shift to a procoagulant state with induction of tissue factor, production of chemokines such as $\mathrm{MCP}_{-} 1$, and induction of leukocyte adhesion molecules such as intercellular adhesion molecule 1 (43).

The Multiorgan Transplant Research Unit at the Toronto Hospital has an interest in the role of immunemediated thrombosis in the pathogenesis of DXR (Figure 1). Using a rat liver model of xenotransplantation, we have shown that prophylactic infusion of monoclonal antibodies to a cellular procoagulant, fgl-2 prothrombinase, a glycoprotein that cleaves prothrombin to thrombin, prevents thrombosis, platelet adherence and fibrin deposition (51). Studies are underway to determine whether organs from 


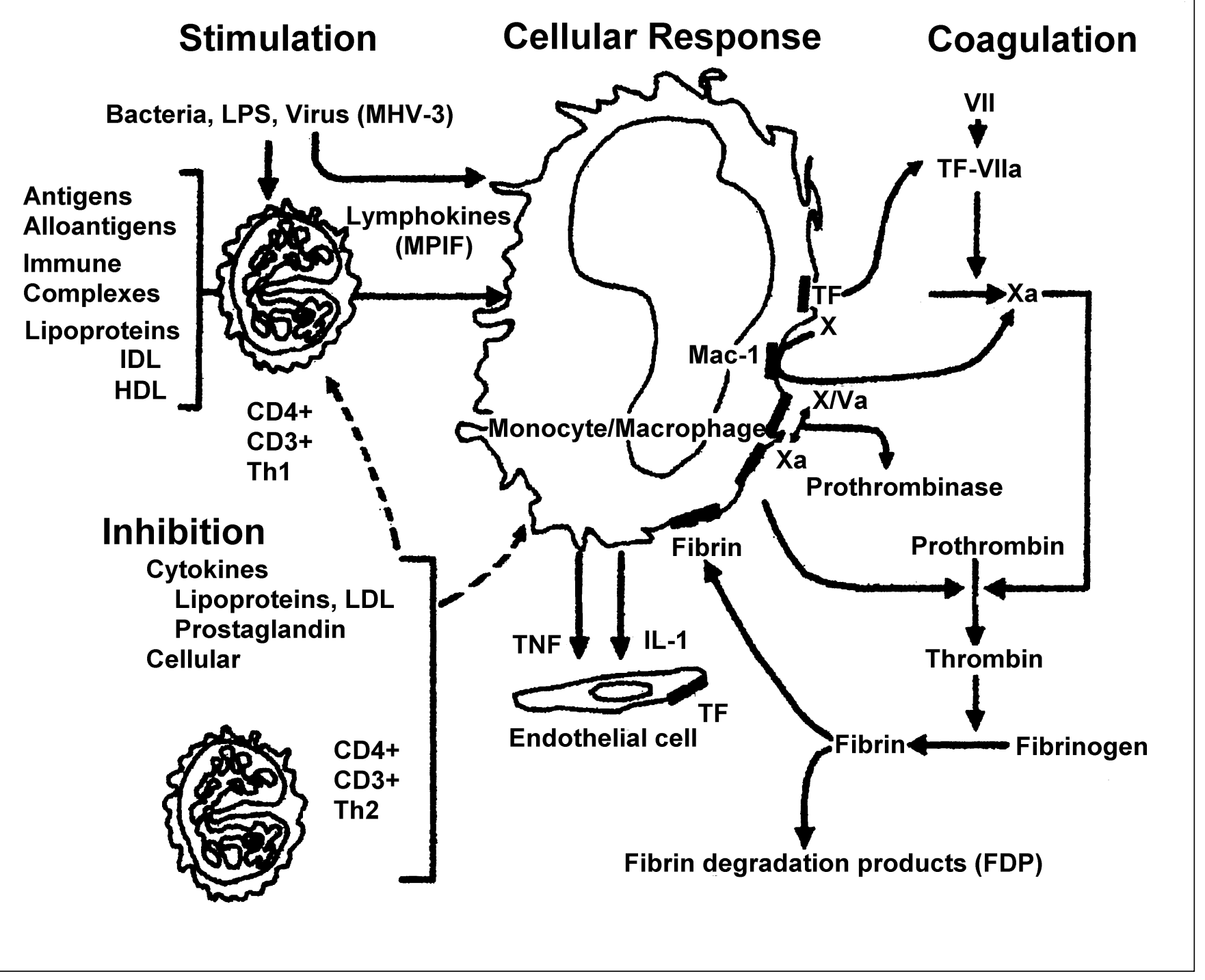

Figure 1) Pathways for stimulation and inhibition of monocyte/macrophage and endothelial cell procoagulant activity. HDL High density lipoprotein; IDL Intermediate density lipoprotein; IL-1 Interleukin 1; LDL Low density lipoprotein; LPS Lipopolysaccharide; Mac-1 Macrophage 1; MHV-3 Murine hepatitis virus strain 3; MPIF Monocyte procoagulant inducing factor; Th1 T helper 1; TF Tissue factor; TNF Tumour necrosis factor

animals in which the prothrombinase gene has been disrupted undergo DXR when transplanted into recipient animals. Another potential therapeutic strategy is to vaccinate animals with soluble prothrombinase so that they may produce neutralizing antibodies to this procoagulant before xenotransplantation. The likely role of endothelial activation in the pathogenesis of DXR suggests additional approaches for modulating endothelial responses, for example, by regulated targeting of NF-kappa-B-dependent endothelial cell pathways (52). In addition, targeting of platelet aggregation and recruitment and activation of host monocytes - early events in the development of DXR - are potential therapeutic approaches.

\section{CELLULAR/HUMORAL REJECTION}

Xenografted organs that are not destroyed by HAR or DXR are subject to elicited cellular and/or humoral rejection (18). In pig to primate transplants, Alexandre et al (53) reversed decreases in graft function by administering immunosuppressive agents. Fryer et al (54) expedited the rejection of guinea pig to rat cardiac xenografts by transferring lymphocytes from presensitized animals. It is not clear how cellular immune responses to a xenograft might differ from responses to allografts, and consequently whether novel therapies for immune modulation might be required. In vitro experiments suggest that $T$ cells stimulated by xenogeneic cells in mixed leukocyte cultures undergo less vigorous proliferation than those stimulated by allogeneic cells (55). This is thought to reflect a limited 
ability of $T$ cells to recognize xenogeneic cells directly (ie, without the contribution of antigen-presenting cells). Conversely, the indirect $T$ cell response to a xenotransplant might be expected to be stronger than that towards an allotransplant, given the wide array of foreign peptides it would give rise to (56). Potent immunosuppressants such as methotrexate, cyclosporine and rapamycin can and have been systemically administered to blunt host $\mathrm{T}$ cell responses to allografts, albeit with a significant risk of infection, malignancy and organ toxicity. A 'tolerant' state, in which the recipient's immune system regards donor antigens as 'self' would obviate the need for chronic immunosuppressive therapy. One approach to induce tolerance involves introducing donor-derived hematopoietic cells before grafting the recipient with a solid organ from the same animal (57). The interaction of two coexisting donor and recipient cell populations is believed to result in mutual down-regulation of both recipient and donor immune systems, a phenomenon known as 'microchimerism' (10). This approach appears to have worked across rodent species but has not been successfully applied across broader species lines (58).

Little is known about the role of the elicited humoral response to a xenograft and whether it differs from what occurs with allografts (53). In a limited number of xenografts in which recipient XRAs are temporarily removed, HAR does not occur even after antibodies return to the circulation (27). This apparent ability of the humoral system and the graft to coexist, known as 'accommodation', may involve a change in the properties or specificity of the antibodies, a change in the antigen, or an acquired resistance of endothelium to humoral injury and complement activation (59). Further understanding of the biological basis of accommodation may prove critical to the clinical application of xenotransplantation.

\section{INFECTIOUS CONCERNS}

Infections have proven to be a substantial cause of morbidity and mortality after allotransplantation. This is owing in large part to the immunosuppressive treatment needed to prevent graft rejection. Interspecies transplantation may require greater levels of immune suppression than are currently used for allotransplantation, thereby further increasing the risk of opportunistic infection. An additional risk of xenotransplantation is that of 'xenosis', the transfer of animal-derived infectious pathogens with xenotransplants (Figure 2) (60). This is in contrast to the natural spread of infection between species, referred to as 'zoonosis'. (61) While xenograft recipients are susceptible to infection by bacteria, fungi and parasites, much attention has focused on infection by viral pathogens (Table 2).

Several mechanisms of xenogeneic infection have been identified. A pathogen may be infectious for both the donor species and the human recipient (eg, Toxoplasma gondii). Some animal viruses that are similar to their human counterparts, such as primate cytomegalovirus (CMV), have been documented to produce clinical disease in hu-

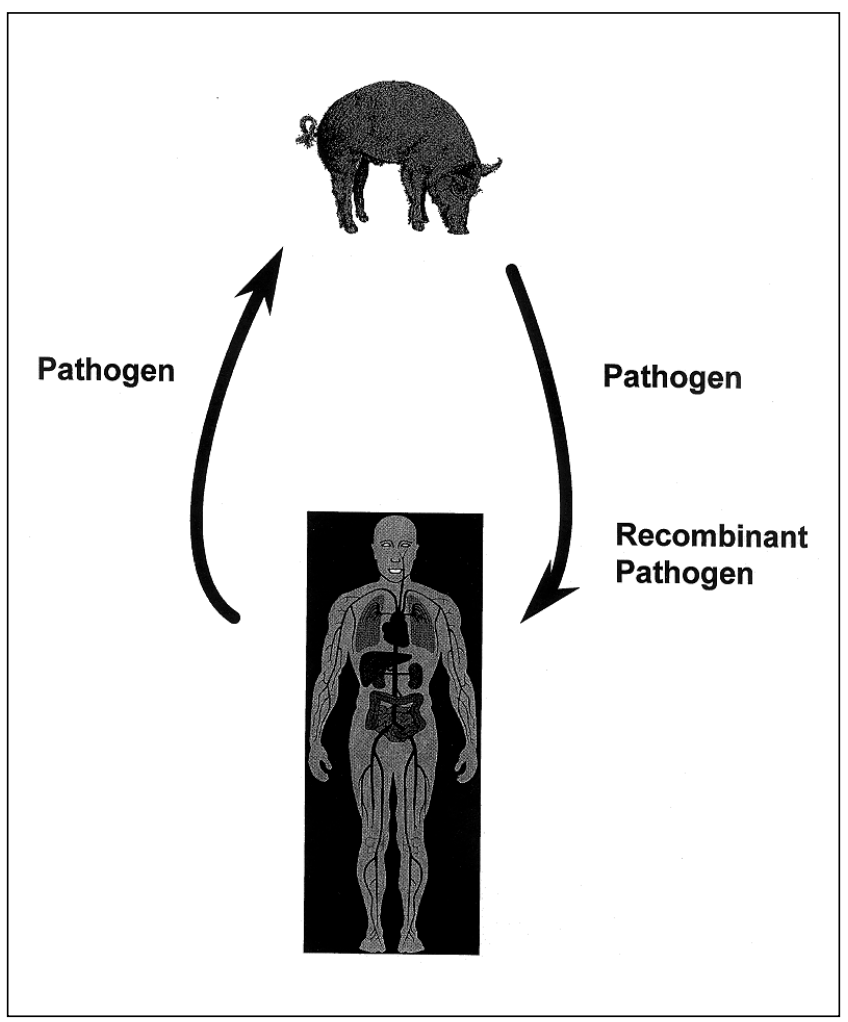

Figure2 ) Zoonosis in xenotransplantation. Pathogens can be infections both from human to pig or from pig to human. In addition, recombination events can occur, resulting in novel pathogens

TABLE 2

Zoonosis in xenotransplantation

\begin{tabular}{l} 
Infectious agents \\
Parasites \\
Bacteria \\
Fungi \\
Viruses \\
Prions \\
Viruses of concern \\
Polyomavirus \\
Parvoviruses \\
Circoviruses \\
Cytomegaloviruses \\
Respiratory syncitial viruses \\
Influenza viruses \\
Retroviruses \\
\hline
\end{tabular}

man xenograft recipients (62). A major concern is retroviruses such as simian immunodeficiency virus, which can be transmitted across species and produce a more virulent reaction in the new host (63). Some pig retroviruses have been shown to reactivate after radiation exposure and might similarly reactivate when exposed to immunosuppressive medication (64). Indeed, many of the conditions associated with retroviral activation (eg, immune suppres- 
sion, graft rejection, cytotoxic therapy) are present in the transplant recipient $(65,66)$. Latent animal viruses present in the xenograft, such as porcine $\mathrm{CMV}$, may be unable to infect human tissue but may later reactivate in the animal organ, resulting in graft failure (60). Finally, concern has been raised regarding the possibility of crossover of an animal virus with a human virus, leading to a more virulent recombinant organism. Indeed, dual infections can lead to recombination, as has been observed with in vitro mixing of CMV isolates from transplant recipients (67). Concurrent inoculation of two avirulent herpes simplex viruses into mice has been demonstrated to produce lethal recombinations (68). Recognition of xenogeneic infections may be complicated by the presence of novel pathogens for which laboratory testing is not available, new clinical syndromes and altered behaviour of these pathogens in the immunocompromised recipient.

Pathogens considered most likely to cause human disease should be screened for and excluded from source animals. Careful thought must be given to determining the organisms to be screened. Algorithms have been developed for baboon bone marrow transplantation into a human to help classify potential microorganisms in source baboons (69). Pathogens were designated as absolute contraindications if they were known to causes zoonoses in primates and known to be hazardous to humans. In particular, organisms that could be secondarily transmitted from an infected recipient to close contacts, such as simian immunodeficiency virus, $T$ gondii and Mycobacterium tuberculosis, were placed in this category. Viruses at high risk for recombination, such as parvovirus and rotavirus, were also designated absolute contraindications. Relative contraindications included organisms suspected to be transmissible but of unproven or unclear clinical significance, such as baboon herpesviruses. Treatable infections were those that could be identified and eradicated successfully before harvest, such as Babesia species. Lastly, a category called 'unavoidable' included baboon endogenous virus and all organisms yet to be recognized. Similar categories have been designed for microbial agents in pigs (70). Molecular techniques to screen source animals for retroviruses, herpesviruses and other organisms are being developed, but much remains to be learned in this field (71). Source animals should be raised in a gnotobiotic environment to eliminate microbial agents. Maintaining pathogen-free environments is an arduous task because colonies can easily be contaminated by unwanted organisms introduced from outside animals or human caretakers (72).

Prevention of disease from human donors has relied on protocols for donor screening, recipient prophylaxis and intensive post-transplantation surveillance. Similar protocols for screening of source animals and surveillance of xenograft recipients can help prevent and monitor infections. Research must, therefore, focus on the behaviour of known pathogens in the transplant recipient. Newer po- tential pathogens must be isolated and characterized, and diagnostic tests must be developed.

\section{ETHICAL, SOCIAL AND ECONOMIC CONSIDERATIONS}

Xenotransplantation is potentially a reliable, long term solution to the current donor shortage for allotransplantation. At the same time, it presents a number of complex ethical, social and economic issues that must be resolved before it can be fully implemented. Unlike other areas of clinical medicine, xenotransplantation raises a variety of ethical issues that have not been formally discussed or agreed upon in the public arena. The general public must play a role in defining ethical policies regarding xenotransplantation, and it is the duty of the medical and scientific communities to provide as much information as possible to them, so that public policies can be formulated in an informed manner.

The clinical application of xenotransplantation is predicated on the assumption that the use of animals in medical research and therapy is morally acceptable. Even if this debatable principle is accepted, the use of animals in xenotransplantation, particularly nonhuman primates, raises additional issues. That these animals may need to be genetically altered to overcome certain immunological obstacles further complicates their use as experimental subjects. As a minimum requirement, the use of source animals for xenotransplantation have to comply with the Canadian Council on Animal Care's Guide to the Care and Use of Experimental Animals $(73,74)$.

The issue of informed consent in xenotransplantation, as in any other area of medicine, requires that the subject be made aware of its potential benefits and risks. In the case of xenotransplantation, there are additional considerations that may violate some of the principles of informed consent. Early recipients of xenografts typically have poor rates of survival, so treatment of these subjects in experimental protocols may raise serious ethical concerns. While the potential benefits and risks of rejection may be estimated, the risk of xenozoonoses cannot reliably be predicted, particularly when DNA from different species is mixed, and may result in new and unpredictable infectious agents. For example, it was only recently determined that porcine endogenous retroviruses can infect human cells (75). The transplant recipient has to agree to the requirement for strict postoperative monitoring, which may result in quarantine or other physical constraints should the recipient develop an infection potentially communicable to the community. This requirement may also extend to household members and other close contacts, and would violate another proviso of informed consent - the right to withdraw from the experiment at any time (76). Hence, in the clinical application of xenotransplantation, 'informed consent' may need to be replaced with a more binding 'contract' between doctor and patient. 
For xenotransplantation to become a clinical reality, substantial financial resources have to be invested to establish facilities for rearing and monitoring source animals, developing laboratory tests, training staff, monitoring recipients and close contacts, and establishing infection control measures. Use of these resources in the development of xenotransplantation technology might result in fewer dollars being available for other equally important medical interventions. If, in the long term, the cost of xenotransplantation drops sufficiently to justify its widespread introduction, there would be additional cost implications for an already cash-strapped Canadian health care system.

\section{REFERENCES}

1. Munoz SJ. Long-term management of the liver transplant recipient. Med Clin N Am 1996;80:1103-20.

2. Spital A. The shortage of organs for transplantation: where do we go from here? N Engl J Med 1991;325:1243-6.

3. Hauptman PJ, O'Connor KJ. Procurement and allocation of solid organs for transplantation. N Engl J Med 1997;336:422-31.

4. Virnig BA, Caplan AL. Required request: what difference has it made? Transplant Proc 1992;24:2155-8.

5. Strategies for cadaveric organ procurement. Mandated choice and presumed consent. Council on Ethical and Judicial Affairs, American Medical Association. JAMA 1994;272:809-12.

6. Andres A, Morales JM, Lloveras J. Reuse of a transplanted kidney. N Engl J Med 1993;328:1644.

7. Moreno EG, Garcia GI, Gonzalez-Pinto I, Gomez SR, Loinaz SC. Successful reuse of a liver graft. Br J Surg 1991;78:813-4.

8. Lanza RP, Cooper DKC, Chick WL. Xenotransplantation. Sci Am $1997 ; 277: 54-9$.

9. Reemtsma K, McCracken BH, Schlegel JU, et al. Renal heterotransplantation in man. Ann Surg 1964;160:384-410.

10. Starzl T, Demetris A, Murase N, Ildstad S, Ricordi C, Trucco M. Cell migration, chimerism, and graft acceptance. Lancet 1992;339:1579-82.

11. Luo Y, Taniguchi S, Kobayashi T, Niekrasz M, Cooper D. Screening of baboons as potential liver donors for humans. Transplant Proc 1996;28:855.

12. Platt, JL. Xenotransplantation: recent progress and current perspectives. Curr Opin Immunol 1996;8:721-8.

13. Platt JL, Lindman BJ, Chen H, Spitalnik S, Bach F. Endothelial cell antigens recognized by xenoreactive antibodies. Transplantation 1990;50:817-22.

14. Platt JL, Turman MA, Noreen HJ, Fischel RJ, Bolman RM, Bach $\mathrm{FH}$. An ELISA assay for xenoreactive natural antibodies. Transplantation 1990;49:1000-1.

15. Galili U, Clark MR, Shohet SB, Buehler J, MacHer BA. Evolutionary relationship between the natural anti-Gal antibody and the Gal $\alpha 1-3 \mathrm{Gal}$ epitope in primates. Proc Natl Acad Sci USA 1987;84:1369-73.

16. Galili U, Shohet SB, Kobrin E, Stults CLM, Macher BA. Man, apes, and Old World monkeys differ from other mammals in the expression of $\alpha$-galactosyl epitopes on nucleated cells. J Biol Chem $1988 ; 263: 17755-62$.

17. Collins BH, Cotterell AH, McCurry KR, et al. Hyperacute rejection of cardiac xenografts between primate species: evidence to support the significance of the $\alpha$-Galactosyl determinant. J Immunol 1995;154:5500-10.

18. Sachs DH, Sablinski T. Tolerance across discordant xenogeneic barriers. Xenotransplantation 1995;2:234-9.

19. Leventhal JR, Matas AJ, Sun LH, et al. The immunopathology of cardiac xenograft rejection in the guinea pig to rat model. Transplantation 1993;56:1-8.

20. Leventhal JR, Dalmasso AP, Cromwell JW, et al. Prolongation of cardiac xenograft survival by depletion of complement. Transplantation 1993;55:857-66.

21. Pruitt SK, Kirk AD, Bollinger RR, et al. The effect of soluble complement receptor type 1 on hyperacute rejection of porcine xenografts. Transplantation 1994;57:363-70.
22. Magee JC, Collins BH, Harland RC, et al. Immunoglobulin prevents complement mediated hyperacute rejection in swine-to-primate xenotransplantation. J Clin Invest 1995;96:2404-12.

23. Brauer RB, Baldwin WM III, Daha MR, Pruitt SK, Sanfilippo F. Use of C6-deficient rats to evaluate the mechanism of hyperacute rejection of discordant cardiac xenografts. J Immunol 1993;151:7240-8.

24. Dalmasso AP, Vercellotti GM, Fischel RJ, Bolman RM, Bach FH, Platt JL. Mechanism of complement activation in the hyperacute rejection of porcine organs transplanted into primate recipients. Am J Pathol 1992;140:1157-66.

25. Hourcade D, Holers VM, Atkinson JP. The regulators of complement activation (RCA) gene cluster. Adv Immunol 1989;45:381-416.

26. Dalmasso AP, Vercellotti GM, Platt JL, Bach FH. Inhibition of complement-mediated endothelial cell cytotoxicity by decay accelerating factor: potential for prevention of xenograft hyperacute rejection. Transplantation 1991;52:530-3.

27. Platt JL, Vercellotti GM, Dalmasso AP, et al. Transplantation of discordant xenografts: a review of progress. Immunol Today 1990;11:450-6.

28. Miyagawa $\mathrm{S}$, Hirose $\mathrm{H}$, Shirakura, et al. The mechanism of discordant xenograft rejection. Transplantation 1988;46:825-30.

29. Medof ME, Kinoshita T, Nussenzweig V. Inhibition of complement activation on the surface of cells after incorporation of decayaccelerating factor (DAF) into their membranes. J Exp Med 1984;160:1558-78.

30. McCurry KR, Kooyman DL, Alvarado CG, et al. Human complement regulatory proteins protect swine-to-primate cardiac xenografts from humoral injury. Nat Med 1995;1:423-7.

31. Saadi S, Platt JL. Transient perturbation of endothelial integrity induced by antibodies and complement. J Exp Med $1995 ; 181: 21-31$.

32. Platt JL, Vercellotti GM, Lindman BJ, Oegema TR Jr, Bach FH, Dalmasso AP. Release of heparan sulfate from endothelial cells: implications for pathogenesis of hyperacute rejection. J Exp Med 1990;171:1363-8.

33. Ihrcke NS, Platt JL. Shedding of heparan sulfate proteoglycan by stimulated endothelial cells: evidence for proteolysis of cell surface molecules. J Cell Physiol 1996;168:625-37.

34. Hattori R, Hamilton KK, Fugate RD, McEver RP, Sims PJ. Stimulated secretion of endothelial von Willebrand factor is accompanied by rapid redistribution to the cell surface of the intracellular granule membrane protein GMP-140. J Biol Chem 1989;264:7768-71.

35. Geng JG, Bevilacqua MP, Moore KL, et al. Rapid neutrophil adhesion to activated endothelium is mediated by GMP- 140 . Nature 1990;343:757-60.

36. Hancock WW. The past, present, and future of renal xenotransplantation. Kidney Int 1997;51:932-44.

37. Ye Y, Neethling FA, Niekrasz M, et al. Evidence that intravenously administered $\alpha$-galactosyl carbohydrates reduce baboon serum cytotoxicity to pig kidney cells (PK15) and transplanted pig hearts. Transplantation 1994;58:330-7.

38. Cooper DKC, Thall AD. Xenoantigens and xenoantibodies: their modification. World J Surg 1997;21:901-6.

39. Tearle RG, Tange MJ, Zannettino ZL, et al. The $\alpha-1,3$-galactosyltrasnferase knockout mouse. Transplantation 1996;61:13-9.

40. Alvarado CG, Cotterell AH, McCurry KR, et al. Variation in the level of xenoantigen expression in porcine organs. Transplantation 1995;59:1589-96.

41. Sandrin MS, Fodor WL, Mouhtouris E, et al. Enzymatic remodelling of the carbohydrate surface of a xenogeneic cell substantially reduces human antibody binding and complement-mediated cytolysis. Nat Med 1995;1:1261-7.

42. Sharma A, Okabe JF, Birch P, Platt JL, Logan JS. Reduction in the level of gal $(\alpha 1,3)$ gal in transgenic mice and pigs by the expression of an $\alpha(1,2)$ fucosyltransferase. Proc Natl Acad Sci USA 1996;93:7190-5.

43. Blakely ML, Vanderwerf WJ, Berndt MC, Dalmasso AP, Bach FH, Hancock WW. Activation of intragraft endothelial and mononuclear cells during discordant xenograft rejection. Transplantation 1994;58:1059-66.

44. Cotterell AH, Collins BH, Parker W, Harland RC, Platt JL. 
The humoral immune response in humans following cross-perfusion of porcine organs. Transplantation 1995;60:861-8.

45. Leventhal JR, Sakiyalak P, Witson J, et al. The synergistic effect of combined antibody and complement depletion on discordant cardiac xenograft survival in nonhuman primates. Transplantation 1994;57:974-8.

46. Hancock WW. Delayed xenograft rejection. World J Surg 1997;21:917-23.

47. Hancock WW. Chemokines and the pathogenesis of $T$ cell-dependent immune responses. Am J Pathol 1996;148:681-4.

48. Zehr KJ, Herskowitz A, Lee PC, Kumar P, Gillinov AM, Baumgartner WA. Neutrophil adhesion and complement inhibition prolongs survival of cardiac xenografts in discordant species. Transplantation 1994;57:900-6.

49. Malyguine AM, Platt JL, Saadi S, Dawson JR. Human natural killer cells induce morphologic changes in porcine endothelial cell monolayers. Transplantation 1996;61:161-4.

50. Goodman DJ, Albertini MV, Willson A, Millan MT, Bach FH. Direct activation of porcine endothelial cells by human natural killer cells. Transplantation 1996;61:763-71.

51. Levy GA, Marsden P, Zhong R, Cole EH, Grant D. Strategies to prevent thrombosis in xenotransplants. Transplant Proc 1998;30:2458-60.

52. Bach FH, Robson SC, Ferran C, et al. Endothelial cell activation and thromboregulation during xenograft rejection. Immunol Rev 1994;141:5-30.

53. Alexandre GP, Squifflet JP, De Bruyere M, et al. Present experience in a series of $26 \mathrm{ABO}$-incompatible living donor renal allografts. Transplant Proc 1987;19:4538-42.

54. Fryer JP, Leventhal J, Dalmasso A, et al. Beyond hyperacute rejection. Accelerated rejection in a discordant xenograft model by adoptive transfer of specific cell subsets. Transplantation 1995;59:171-6.

55. Alter BJ, Bach FH. Cellular basis of the proliferative response of human $\mathrm{T}$ cells to mouse xenoantigens. J Exp Med 1990;191:333-8.

56. Wrenshall LE, Cerra FB, Singh RK, Platt JL. Heparan sulfate initiates signals in murine macrophages leading to divergent biological outcomes. J Immunol 1995;154:871-80.

57. Starzl TE, Demetris A, Trucco M, et al. Cell migration and chimerism after whole-organ transplantation: the basis of graft acceptance. Hepatology 1993;17:1153-6.

58. Gritsch HA, Glaser RM, Emery DW, et al. The importance of nonimmune factors in reconstitution by discordant xenogeneic hematopoietic cells. Transplantation 1994;57:906-17.

59. Platt JL, Fischel RJ, Matas AJ, Reif SA, Bolman RM, Bach FH. Immunopathology of hyperacute xenograft rejection in a swine-to-primate model. Transplantation 1991;52:214-20.

60. Fishman JA. Miniature swine as organ donors for man: strategies for prevention of xenotransplant-associated infections. Xenotransplantation 1994;1:47-57.

61. Michaels MG, Simmons RL. Xenotransplant-associated zoonoses: strategies for prevention. Transplantation 1994;57:1-7.

62. Michaels MG, McMichael JP, Brasky K, et al. Screening donors for xenotransplantation. The potential for xenozoonoses. Transplantation 1994;57:1462-5.

63. Benveniste RE, Morton WR, Clark EA, et al. Inoculation of baboons and macaques with SIV/mne, a primate lentivirus closely related to HIV 2. J Virol 1988;62:2091-101.

64. Frazier ME. Evidence for retrovirus in miniature swine with radiation- induced leukemia or metaplasia. Arch Virol 1985;83:83-97.

65. Hirsch MS, Ellis DA, Black PA, Monaco AP, Wood ML. Leukemia virus activation during homograft rejection. Science 1973;180:500-2.

66. Olding LB, Jensen FC, Oldstone MB. Pathogenesis of cytomegalovirus infection. I. Activation of virus from bone-derived lymphocytes by

in vitro allogeneic reaction. J Exp Med 1975;141:561-6.

67. Chou S. Reactivation and recombination of multiple cytomegalovirus strains from individual organ donors. J Infect Dis 1989;160:11-5.

68. Javier RT, Sedarati F, Stevens JG. Two avirulent herpes simplex viruses generate lethal recombinants in vivo. Science 1986;234:746-8.

69. Michaels MG, Hilliard J, Deeks S, et al. Baboon bone marrow xenotransplant in a patient with advanced HIV: a model for the evaluation of potential xenozoonoses. J Acquir Immune Defic Syndr Hum Retrovirol 1997;11:3. (Abst)

70. Ye Y, Niekrasz M, Kosanke S, et al. The pig as a potential organ donor for men. Transplantation 1994;57:694-703.

71. Murphy FA. The public health risk of animal organ tissue transplantation into humans. Science 1996;273:746-7.

72. Lerche NW, Yee JL, Jennings MB. Establishing specific retrovirus-free breeding colonies of macaques. Lab Anim Sci 1994;44:217-21.

73. Guide to the Care and Use of Experimental Animals, vol 1. Ottawa: Canadian Council on Animal Care, 1993.

74. Guide to the Care and Use of Experimental Animals, vol 2. Ottawa: Canadian Council on Animal Care, 1994.

75. Patience C, Takeuchi Y, Weiss RA. Infection of human cells by an endogenous retrovirus of pigs. Nat Med 1997;3:282-6.

76. Daar AS. Ethics of xenotransplantation: animal issues, consent, and likely transformation of transplant ethics. World J Surg 1997;21:975-82.

77. Canadian Organ Replacement Register, 1998 Report, vol 2: Organ Donation and Transplantation. Ottawa: Canadian Institute for Health Information, 1998. 


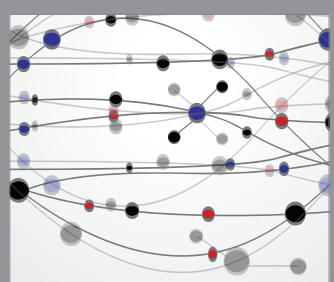

The Scientific World Journal
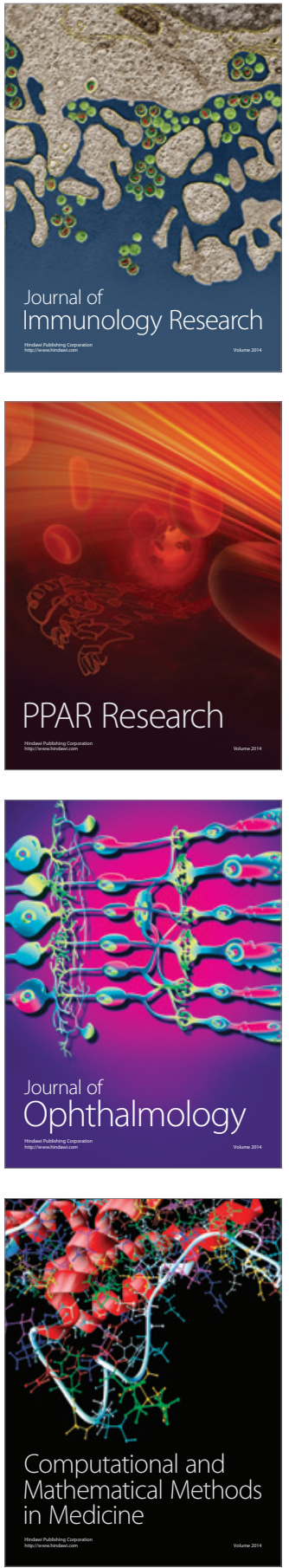

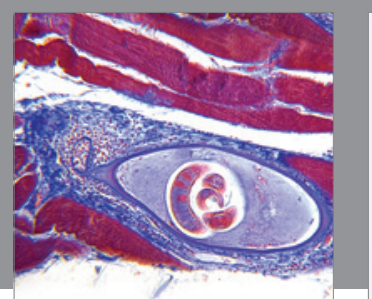

Gastroenterology Research and Practice

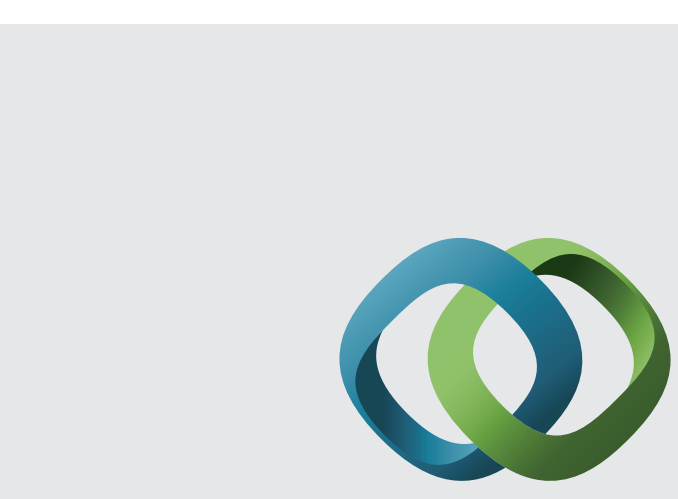

\section{Hindawi}

Submit your manuscripts at

http://www.hindawi.com
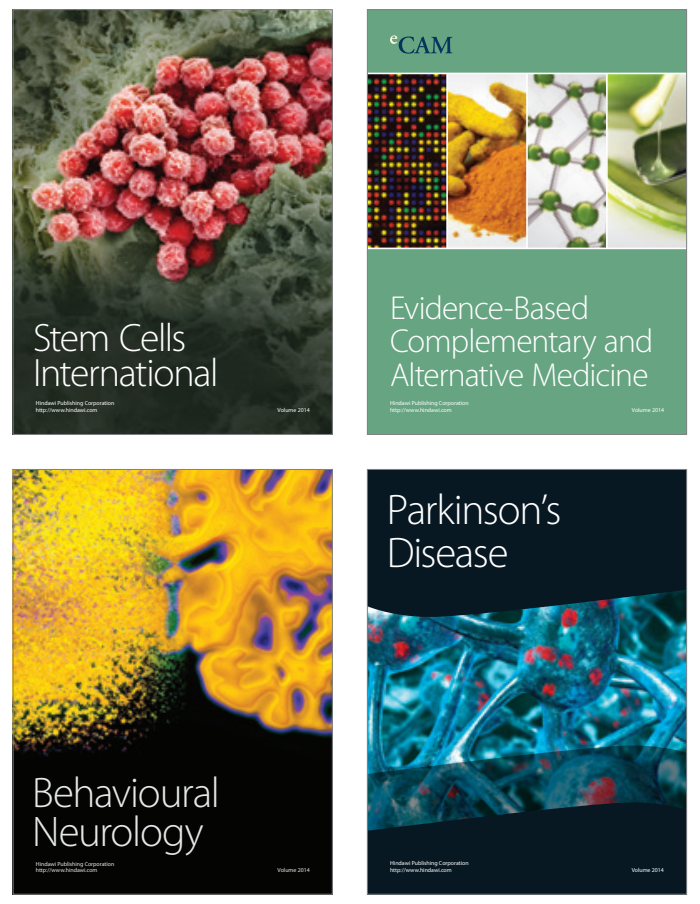
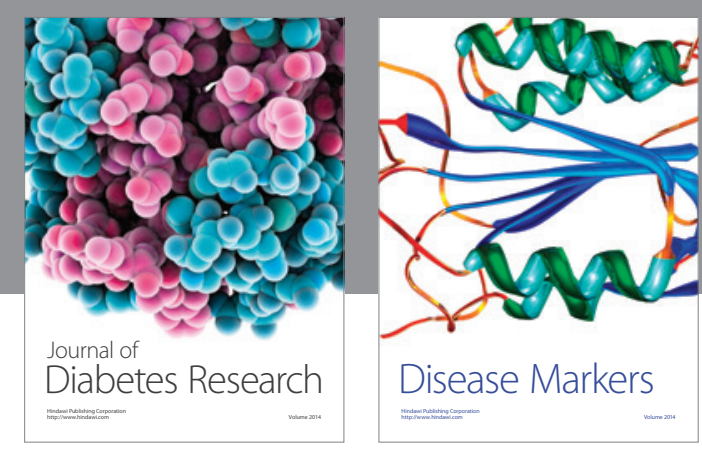

Disease Markers
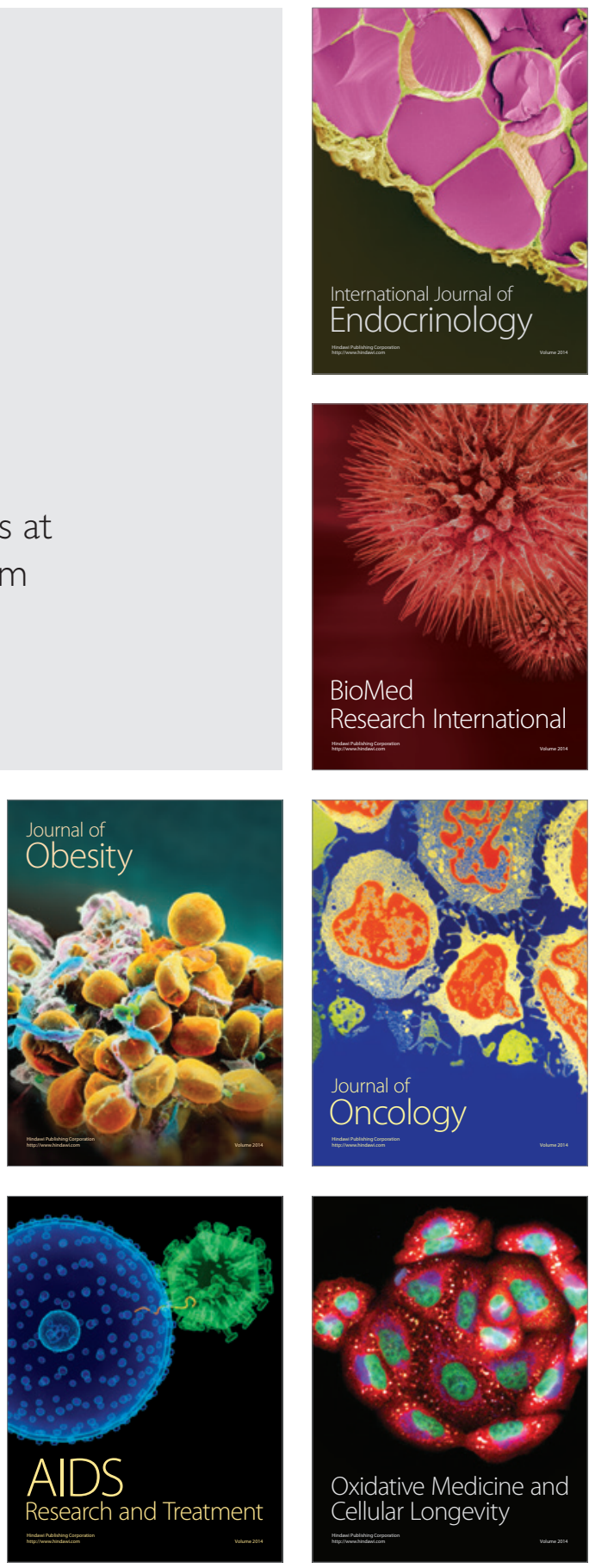